\title{
SELAMETAN (SALVATION) TRADITION IN ISLAM OVERVIEW
}

\author{
Nanik Mindarnengsih, S.Pd. \\ Universitas Muhammadiyah Sidoarjo \\ Email: nanikmustofa@gmail.com
}

\begin{abstract}
Islam religion is the biggest religion in Indonesia and the most adhered with $87.2 \%$ of population. Islam in Indonesia is roughly considered to have gradually spread through merchant activities by Arab Muslim traders, adoption by local rulers and the influence of mysticism since the 13th century. This research uses descriptive method to explain data collection in the field, which provides an overview of Selametan (Salvation) Tradition in Islam overview. Research approach uses a anthropolgy qualitative approach. Data are written results from interviews, observation, and documentations in Salvation Tradition. Data sources are from Javanese People. The results of this research mentions that Salvation Tradition is a good tradition about praying attitude of $k h u d h u^{\prime}$ and khusyu' to Allah but It must be followed with traditional ceremony based on the Javanese Ancestors. Research focus is related with Islam overview that Islam does not teach about Salvation in order to get bless from ancestor. From the statement above, Islam believes that getting bless can be done by making Qur'an recitation as anual event.
\end{abstract}

Keywords: Religion, Islam, Salvation, Selametan, Tradition, Qualitative Approach, Recitation, Overview.

\section{A. INTRODUCTION}

Islam is a religion whose spread is quite extensive in Indonesia. It can be proof by many Islamic days as holiday is celebrated by almost $80 \%$ citizen, which is the highest Muslim population in Indonesia.

Islam in Indonesia is roughly considered to have gradually spread through merchant activities by Arab Muslim traders, adoption by local rulers and the influence of mysticism since the 13th century. During the late colonial era, it was adopted as a rallying banner against colonialism.

Islam became the dominant religion in Java at the end of the 16th century. During this era, the Islamic kingdoms of Demak, Cirebon, and Banten were ascendant. The Mataram Sultanate became the dominant power of central and eastern Java at the end of the 16th century.
Thus, Islam influence is very large in Indonesia, especially in Java Island. This has concerned with the arrival process of Islam on the Java island, which has a wide influence. The influence has various aspects, including economic, political, and socio-cultural aspects.

Through a long process of Islam, it has be able for slowly stepping on strongly Javanese society. The influence is also leading a new way with various specific Indonesian Culture society.

Indonesia is a country that has a diverse culture. This diversity is based on the geographical location of Indonesia in the world trade area. ${ }^{1}$

Many traders come to Indonesia while they are trading, spreading, and bringing their cultures and religion from

\footnotetext{
${ }^{1}$ Fischer, H. TH. Pengantar Anthropologi Kebudayaan Indonesia, terj. Anas Makruf. Jakarta: Pustaka Sardjana, 1953
} 
their origin. That is why, that causes some acculturation in culture that comes from Hinduism, which had entered in Indonesia before Islam religion.

Religious studies today have emerged and used Anthropology as the basic approach. Various approaches about understanding religion that have used so far before. They are seen to be complemented by anthropological approaches. From those problems, we need to raise Islamic religious thoughts by collaborating between Islamic religion and Hindu-based culture.

That statement has inherent in cultural circles namely Islam which is in Java Island. As the example is a case of "Javanese Marriage Salvation Traditional from Islam Overview". That case study hass faced with Javanese culture perspective that collaborates with Islam as form of salvation by reading Al-Qur'an.

Based on the statement above, this research focuses on Selametan (salvation) tradition in Islam overview. ${ }^{2}$ Here author tries to explain the focus through anthropological approach.

\section{B. METODE PENELITIAN}

This research method uses descriptive method that has carried out through data collection in the field, which provides an overview anthropological approach. Therefore, this research can describe Islamic overview about Salvation Tradition.

Descriptive method according to Sugiyono is a research method that aims to describe, explains the conditions that has exist in the company based on facts. The characteristics of the population is based on the data that has collected and then arranged systematically and subsequently analizing for conclusion.

Research data is about The Selametan (Salvation) tradition itself,

\footnotetext{
${ }^{2}$ Koentjaraningrat. Kebudayaan Jawa. Jakarta: Balai Pustaka, 1984
}

which is coming from by interviewing and recording. The results are showing into phrases and sentences.

Research data source is coming from the tradition region representative, society, and customary leader, who knows about Selametan Tradition.

\section{RESEARCH DISCUSSIONS Anthropology}

Anthropology is a science about humans, the past and present, which explains humans through knowledge of social sciences and life sciences (nature) and also the humanities. Anthropology is also called the study of humans based on culture, behavior, diversity and so forth.

Anthropology is a Greek word term derived from the words anthhopos and logos. Antrhopos means human and logos means story or word. Anthropology object is humans. Anthropology aims for studying humans in ethnic groups, behaviours, and cultures to help the community and society.

Antrhopologists in general agree that Selametan (salvation) is the core ritual in Javanese (Muslim) society.

Before the writer discuss it more detail, we introduce first about Java and Javanese society.

Java

Java is famous for its combination of diverse cultural forms and religious belief. Java has many tribes which has different culture and custom. Thus are Sundanese, Javanese, and Madurese.

\section{Javanese}

Javanese are know as the tribe with the largest population in all Indonesia. Almost in every island in Indonesia, the Javanese must always exist.

Javanese are an ethnic group native to the Indonesian island of Java. Javanese ethnic group has many sub groups, such as the Mataram, Cirebonese, Osing, Tenggerese, Samin, Naganese, Banyumasan, and others. 
A majority of the Javanese people identify themselves as Muslims with a minority identifying as Christians and Hindus. $^{3}$

Javanese are also known as a friendly personality tribe and also have a remarkable history of tradition and culture.

However, Javanese civilization has been influenced by more than a millennium of interactions between the native animism Kejawen and the Indian Hindu-Budddhist culture, and this influence is still visible in Javanese history, culture, traditions, and art forms.

\section{Javanese Cultures}

Javanese culture is one of the oldest civilisations and has flourished in Indonesia. It has gradually absorbed various elements and influences from other cultures, including native reference for ancestral and natural spirits, Hindu and Buddhist dharmic civilisations, Islamic values, and to a lesser extent, Christianity, Western Philosophy and modern ideas. One of the Javanese culture is Selametan (Salvation).

\section{Selametan (Salvation) Tradition}

Based on KBBI (Indonesian Dictionary Book), Salvation is held a party that is shown a traditional ceremony held by Javanesse society. Yet, Salvation also has done with Sundanesse and Maduranesse society.

Selametan is a form of thanksgiving event by inviting some relatives or neighbors. Traditionally the thanksgiving event begins with a prayer together, by sitting cross-legged on a mat, circling rice cone with side dishes. Slametan comes from the Javanese word "slamet" and most probably in Arabic "salam" as well.

Thus means well being, peace, safety, health, goodness, and in essence it

\footnotetext{
${ }^{3}$ Koentjaraningrat. Kebudayaan Jawa. Jakarta: Balai Pustaka, 1984
}

refers to the state of stasis or simply "nothing happens" to one or to people.

Being Slamet implies that one is safe, it shows a safety condition with no difficulties and also no troubles.

Slametan (Salvation) is the communal feast from Java, symbolizing the social unity of those participating in it. It is considered as the core ritual in Javanese religion, in particular the abangan variant. The feast is common among the closely related Javanese, Sundanese, and Madurese people.

Selametan (salvation) is conducted for generations as a memorial prayer led by traditional elders or religious leaders. The existence of acculturation of Islamic and Javanese culture in the 16th century $\mathrm{AD}$ made this ceremony suffers a great change. At that time, the Hindu/Buddha prayer was originally used then replaced with Islamic prayer. In addition, offerings also becameno longer used in this ceremony.

Selametan (Salvation) ${ }^{4}$ can be given to celebrate almost any occurence, including birth, marriage, death, moving, to a new house, and so forth. Depending on the intenton, the mood, and emphasis may vary somewhat, but the main structure is the same.

Giving Congratulations can be interpreted as a detachment from unwanted incidents.

Meanwhile, Clifford Geertz mentions about Slamet that there is nothing (nothing). Slametan ceremony is one of Javanesse tradition that is considered to be able to bulid a distance from disaster.

Slametan is a universal concept that must exist in every place with a different name. This is because selfawareness is "weak" in the presence of forces outside the human self.

\footnotetext{
${ }^{4}$ Beatty, Andrew. "Adam and Eve and Vishnu: Syncretism in the Javanese Slametan" The Journal of the Royal Anthropological Institute, Vol. 2, No. 2 (Jun., 1996), pp. 271-288
} 
The ceremony takes its name from the Javaneseword "slamet", the from Arabic which means Salam.

Therefore all that has become the habit of the majority of the community becomes sacred and sacred mythical beliefs. This is what in turn, the custom of tradition has unknowingly become a value system (putten for behavior) for populist society in general. The value system often becomes a guideline for those whose level of sacredness sometimes exceeds the value system of other formal religious texts.

\section{RESEARCH RESULTS}

\section{Islam does not recognize} Selametan (salvation). Why is it not eradicated? Because selametan (salvation) is a Buddhist models and cultures. Selametan (salvation) has feast culture such as ambengan, kupat lepet, porridge (jenang) mirah, and so forth.

Yet, Islam does not have those kind of culture, because Islam teaches about being simple and simply.

\section{Those are not supposed to be eradicated?}

\section{Because there is no light at that time?}

That can be explained as Shodaqoh in principle of Islamic recommendation.

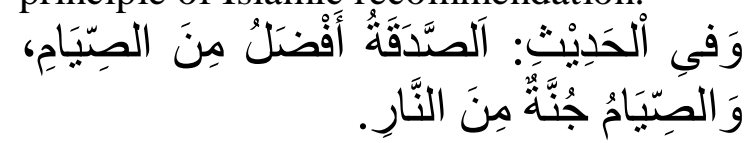

Shodaqoh is more important than fasting, and fasting is a shield from hell. (Narrated by Addailamy Fi Musnadihi Al Firadus)

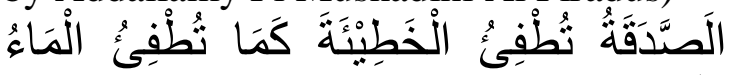
النَّارَ

Shodaqoh can extinguish errors, like water extinguishing a fire. (HR. Addailamy Fi Musnadihi Al Firadus).

The other form of shodaqoh, Islam does not determine, that the Prophet said:

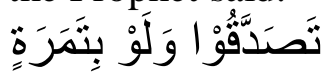

Shodaqoh you, even if it's just a date palm. (Narrated by Al Bukhori). This hadist shows that shodaqoh, in whatever form and in any number, Prophet Muhammad did not determine.
Sadaqah (voluntary charity) is a virtuous deed in Islam. In fact, it is considered as a proof of one's eeeman (faith).

Based on Abu Malik Al-Ashari, he narrated Allah's message that "Cleanliness is half of faith".

Sadaqah is not restricted to giving part of our wealth or material possessions or any special deed or righteousness. Since sadaqah is not limited to give money or part of our wealth, every Muslim can earn rewards from Allah. Therefore, sadaqah is an easy way to increase our eeman.

If we want to enjoy Allah's tremendous rewards in our sadaqah, we nedd to follow these steps suc as: 1) Sadaqah must be done sincerely for the pleasure of Allah and not out of riya' (show off) to gain praise or recognition from others; 2) Sadaqah is better to conceal what we give or do: 3) Sadaqah must be from Halal (lawful) sources; 4) Begin charity with your dependents; 5) Not to delay giving of sadaqah nor show lethargy or negligence in giving sadaqah; Do not count the sadaqah you give; and 7) Seek only the desire to see Allah which is the supremesuccess in Paradise.

\section{Difference with Selametan (salvation) and Sadaqah. \\ Selametans (Salvations) is coming} from Hinduism culture. Selametan (salvations) purposes to pray to God $\mathrm{Al}$ Mighty, which is based on Hinduism belief.

Yet, Selametan also has similarity with sadaqah, which is sharing to someone else without giving any options and also any obstacles. ${ }^{5}$

Selametan has its own procedures. The procedures are generally held in the evening, after evening prayer is finished. The date is determined either by the occurance it is celebrating, for whom, or

\footnotetext{
${ }^{5}$ Woodward, Mark R.. "The "Slametan": Textual Knowledge and Ritual Performance in Central Javanese Islam." History of Religions, Vol. 28, No. 1 (Aug., 1988), pp. 54-89
} 
on auspicious days in the Javanese calendar. The guests, always, men, are always close neighbours, and theselection of guests is based entirely on proximity, and not whether they are friends or relatives. Selametan feast has some kinds of typical food, they are porridge (jenang), roasted chicken, sticky kupat, and ambeng.

Then for Sadaqah, it does not have typical food. It is based on our will to give anything to someone else as long as we feel free (Ikhlas). Sometime, it is just a short word in the form of anything, although only with a date palm, suffice for shodaqoh.

From the statement above, It can be seen that Selametan (salvation) has similarity with Shodaqoh, but it relates with Java tradition, which is carried out in the form of ambeng, jenang, kupat lepet, and so on.

Selametan (salvation) custom does not conflict with Islam. Indeed, This custom just be used to give respect to the nine of saints in ancient times ( \pm five hundred years ago). It means that this custom as an inherent tradition from Java to memorize the struggle of the saints to maintain Java Island in spreading Islam in Java. The saints were very wise and very helpfull at that time. The saints itself are knowns as Wali Songo.

Thus custom is not contradictory with Islam and also not eradicated at all. Both customs are how to dress, how to settle down, how to socialize and others.

Therefore, Selametan (salvation) feast has different type of food that each food gives different ideology and purpose. They are ambengan (tumpeng), porridge (jenang), and kupat/ketupat. ${ }^{6}$

Ambengan (Tumpeng).

Ambengan is about Ambeng Rice. Nasi ambeng is often served communal dining-style on a platter to be shared

\footnotetext{
${ }^{6}$ Newberry, Jan. "Rituals of Rule in the Administered Community: The Javanese Slametan Reconsidered." ModernAsian Studies. Published online January 2007
}

among four to five people; especially during festive and/or special occasions such as a kenduri.

Rice ambeng is a Javanese dish which is white rice placed on top of a table and given side dishes around it. Side dishes consist of cakes, fried salted fish, peanut butter, fried chili sauce, boiled eggs, fried tempeh, urap, fried rice noodles, and chicken opor.

Rice ambeng is a dish that is served in selametan (salvation) as a sign of gratitude. Rice is eaten in a roll by four to five adults. Rice is eaten by hand, without blades and garfu. The presentation of ambeng rice contains a request that all parties who participate be blessed with a lot of sustenance.

Lately a lot has happened, replaced with takiran (rice box). Try to compare. If 20 people are invited to salvation, there are also 20 takiran supplies, then for some reason 30 people are present.

How to overcome the fate of the ten invitations? But if making ambeng is easy, then those peole who were summoned about 20 people, so there were 30 ambengs. Then there are 30? Alright, now there are 3 ambengs for thirty people.

We will say, "With takiran it's also easy, that is, those who don't carry the invitation letter are rejected." In our opinion, this method does not fit the personality of the East people, especially the Javanese. The feeling of the east is very subtle. If he invited his neighbors to attend the circumcision ceremony, for example, then there were also some people who were not invited to come, so he did not have the heart to reject them. Here, this is a useful location rather than ambeng.

\section{Porridge (jenang).}

Jenang in Javanese society has taken root since the Hindu era. Jenang tradition also existed during the Walisongo era even today.

Jenang is always present as a symbol of gratitude to God. In all rituals of selametan (salvation) for Javanese people 
and surrounding areas, typical food in the form of jenang is always present.

Jenang is generally made from rice flour or sticky rice flour and then cooked with coconut milk and added brown sugar or white sugar.

The typical food is a symbol of prayer, hope, unity and spirit of the Javanese people.

Slamet Raharjo, protector of the Indonesian Jenang Foundation, said that sociologically jenang is a type of culinary that is born from the creativity of the community.

Jenang, continued Slamet, is free from the attributes of social and ethnic status, aka democratic, egalitarian, spiritual and religious.

Food is present in many events, for example salvation for pregnant women will be equipped with procotan jenang. Likewise, when giving a name to a baby after birth, it is made a good luck.

Selametan (Salvation) after the wedding ceremony in the hope that the bride and the entire committee will always be healthy, get blessings and strength, will be equipped with sungsum.

It has become a character for humans, especially Indonesians, besides that they like to receive gifts, they also like giving to others. Even though they might only be given, but never give. They seemed to be if they were only always invited to selametan (salvation), but never invited salvation.

Thus, those people who do not give can also enjoy giving deeds, as gift is in the form of porridge (jenang). The porridge seems appropriate, also the capital is very simple. If a kilogram of rice is used as rice, it is only enough for six people, but if it is distributed porridge it can be enough for fifteen to twenty people. If the rice is at least, it must be delivered by side dishes, but enough porridge is delivered with old coconut and Javanese sugar.

Kupat or ketupat (Sticky Rice)
According to Javanese traditions, the Indonesian lebaran tradition ${ }^{7}$ was first started when Sunan Bonang, one of Wali Songo of Tuban in 15th-century Java, calls for the Muslims to elevate the perfection of their Ramadhan fast by asking forgiveness and forgiving others' wrongdoings. The tradition on preparing and consuming ketupat or kupat in Javanese language during lebaran is believed to be introduced by Raden Mas Sahid or Sunan Kalijaga, one of Wali Songo (nine Muslim saints) that spread Islam in Java.

Sunan Kalijaga introduced the lebaran ketupat ritual on 8 Shawwal, a week after Eid ul-Fitr and a day after a sixday Shawwal fast. It is believed that it contains appropriate symbolism; kupat means ngaku lepat or "admitting one's mistakes" in Javanese language, in accordance to asking for forgiveness tradition during lebaran.

The crossed weaving of palm leaves symbolises mistakes and sins committed by human beings, and the inner whitish rice cake symbolise purity and deliverance from sins after observing Ramadhan fast, prayer and rituals. Other than Java, the tradition on consuming ketupat during Eid ul-Fitr is also can be found throughout Indonesia; from Sumatra, Kalimantan, Sulawesi, Nusa Tenggara.

Kupat or ketupat ${ }^{8}$ ingredients are very simple. Ketupat, which is rather decent, can be quite two tablespoons of rice. Other than that, every year, if we save ketupat, it means we give a warning to our neighbors to stay united.

If two spoons of rice can be divorced, so it cannot be united. Thus

\footnotetext{
${ }^{7}$ Jay Akbar. 2013. "Mengunyah Sejarah Ketupat" (in Indonesian). Historia. Retrieved 1 July 2013

${ }^{8}$ Panca Nugraha and Suherdjoko (5 August 2014). "Muslims celebrate Lebaran Ketupat a week after Idul Fitri". The Jakarta Post. Retrieved 22 January 2015
} 
gathering becomes a heavy object which is not understanding, why does a mindful human being not be able to be united in a framework of diamonds.

From that statement, it can be seen that salvation activities have nothing to do with Islam because salvation is a legacy from the Hindu tradition. That has been attached to the Javanese tradition. While salvation is a lot of definitions given, the point is to ask for prayer to be given fluency, blessing, success in what is lived either in the form of business, business, working out of the area, going on Hajj, going to marry, occupying a new house, and others.

Thus, there are no significant obstacles, unexpected, and beyond the reach of abilities that hinder the journey ahead. The implementation is usually in the form of a celebration ceremony by inviting many people from relatives, close friends, surrounding communities, and also by inviting orphans.

This kind of form was never exemplified by the Prophet sallallaahu 'Alaihi Wasallam, the friends and previous scholars. From here, it appears that there are actually a lot of Hindu cultures that exist in Islamic culture.

Because there is a process of cultural acculturation, then Islam coming into Indonesia has been through artistic channels. Besides the acculturation process is also a part of assimilation in Islamic culture based on integration of Hindu culture with Islamic culture.

We can live within in that circle because we have filter to eliminate the culture so well. Therefore, it breaks the culture of what we have.

\section{E. CONCLUSIONS}

Based on the discussion and results above, it can be concluded that selametan (salvation) is a part of prayer, but is wrapped in a celebration in the form of calling people.

Selametan (salvation) is not a part of Islam religion and also Islam culture, because it comes from Hindu/Buddha culture.

Actually, asking for a prayer from someone who is righteous (who is more likely to be granted a prayer) is fine, even if praying alone is more important, because by praying alone means he is worshiping and will be rewarded.

Praying on your own also fosters an attitude of khudhu 'and khusyu' to Allah, and fosters great hope in Him. While asking for prayers to others, usually, only relying on the prayers of others while there is no more change in this person.

The subject matter is in the form or procedure of praying in the salvation earlier. Namely with celebrations and calling people to ask for prayer without looking at the piety of the people present. And this way has never been an example of the best generation of this people.

It is feared that this includes part of the creation of new cases in Islam which includes acts of sin. Then, the question is what prayer should be read specifically. We can answer it with: there are no demands for special prayers to be read in selametan (salvation). Why is that so? Because there is no example from Islam leader, the Prophet Muhammad and friends, Tabi'in. They never teach bout selametan (salvation). They just teach about Al-Qur'an, which contains Allah S.W.T messages.

If you call them to be pleased with eating and compensation, this is fine and it's the best. Yet, if we get something by reading in certain (special) reading that seems to be a part of routine worship, that is what there is no guidance. The guidance itself is delivered by Allahhu Ta'ala Wallahu'.

Every religion has its own characteristic and method. Yet, their vission and mission is to worship to God Al Mighty, who creates eevery creature in the universe. Thus diversity is very beautiful if we can respect and care to each other. 
Being respectful is also mentioned in Al-Qur'an, surah Al-Kafirun verse 6:

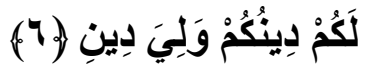

Means that:

"For you, your religion, and for me, my religion"

Based on that surah above, Allah tells that every Islam followers must give their respect to keep peacefullness in their livinghood and environment.

Moreover, Islam also has taught about sharing, caring, loving, and spreading peacefull life to others. Islam teaches its followers based on Al-Qur'an and Hadist. The hadists are coming from Prophet Muhammad S.A.W. Then, Islam also believes that Sadaqah can clean all sins rather than to do selametan (salvation).

Hence, Indonesia has very diverse cultures and traditions. The majority of Indonesians are Muslims; therefore, Indonesia has the largest Muslim population in the world. Indonesia Muslims can be separated from their own cultures and traditions, many of them are still using their cultures and tradition to worship to Allah S.W.T. Whether it is not mentioned and taught in Islam, but if it is good and positive, it can be used for them.

We cannot measure it as good or wrong. Your judgement is based on your thought, no one is true. The truth is only in Allah Ta'alla.

\section{REFERENCES}

\section{Books}

Fischer, H. TH. 1953. Pengantar Anthropologi Kebudayaan Indonesia, terj. Anas Makruf. Jakarta: Pustaka Sardjana

Geertz, Clifford. 1960. The Religion of Java. Glencoe. Illinois: The Free Press.

Koentjaraningrat. 1984. Kebudayaan Jawa. Jakarta: Balai Pustaka.
Prawiro, A.M.B. 2016. Reception through selection-modification: antropologi hukum Islam di Indonesia. Yogyakarta: Deepublish.

Sugiyono. 2015. Metode Penelitian Pendidikan: Pendekatan Kualitatif, Kuantitatif, dan $R \& D$. Bandung: Alfabeta.

Yusuf and Toet. 2014. Indonesia has stories. Jakarta: Penerbit Cerdas Interaktif.

\section{Journal Articles}

Beatty, Andrew. "Adam and Eve and Vishnu: Syncretism in the Javanese Slametan" The Journal of the Royal Anthropological Institute, Vol. 2, No. 2 (Jun., 1996), pp. 271-288.

Hambal, Muhammad. 2015. "Deresan" Program the Mastery of ArabicClassic Book at Pondok Pesantren Karangasem Lamongan East Java Indonesia. Journal of Social Sciences and Humanities, Vol. 1, No. 2, pp. $125-130$

Heriyono (7 August 2013). "Idul Fitri, Kenapa Muslim di Indonesia Makan Ketupat?". Aktual.co (in Indonesian). Aktual.co. Archived from the original on 24 August 2013. Retrieved 9 August 2013.

Jay Akbar. 2013. "Mengunyah Sejarah Ketupat" (in Indonesian). Historia. Retrieved 1 July 2013.

Newberry, Jan. 2007. "Rituals of Rule in the Administered Community: The Javanese Slametan Reconsidered." ModernAsian Studies. Published online January 2007.

Panca Nugraha and Suherdjoko (5 August 2014). "Muslims celebrate 
Lebaran Ketupat a week after Idul Fitri". The Jakarta Post. Retrieved 22 January 2015.

Woodward, Mark R.. "The "Slametan":

Textual Knowledge and Ritual Performance in Central Javanese Islam." History of Religions, Vol. 28, No. 1 (Aug., 1988), pp. 54-89 